\title{
STRUKTUR KOMUNITAS FITOPLANKTON BERDASARKAN SEBARAN TEMPORAL DI PERAIRAN DESA LALANU KABUPATEN KONAWE
}

\section{Phytoplankton Community Structure of Phytoplankton Based on Temporal Distribution on Lalanu Village Waters, Konawe Regency}

\author{
Linda Mirwana $^{1 *}$, Wa Nurgaya ${ }^{1}$, Emiyarti $^{2}$ \\ ${ }^{1}$ Program Studi Ilmu Kelautan, ${ }^{2}$ Program Studi Oseanografi \\ Fakultas Perikanan dan Ilmu Kelautan, Universitas Halu Oleo. \\ Jl. H.E.A Mokodompit Kampus Hijau Bumi Tridharma Anduonohu Kendari 93232, Telp/Fax: (0401) 3193782 \\ *Surel: lindamirwana@gmail.com
}

\begin{abstract}
Abstrak
Struktur komunitas fitoplankton dipengaruhi oleh ketersediaan cahaya, semakin dalam suatu perairan maka intensitas cahaya yang ada dalam perairan tersebut akan semakin menurun. Tujuan dari penelitian ini adalah untuk menganalisis struktur komunitas fitoplankton berdasarkan sebaran temporal di Perairan Desa Lalanu. Pengambilan data dilakukan pada bulan Januari - Februari 2019 di tiga stasiun penelitian. Pengambilan sampel fitoplankton dilakukan selama 13 jam yaitu pagi - sore hari yang dilakukan sebanyak 3 kali ulangan dengan interval waktu pengambilan sampel pagi, siang dan sore hari. Berdasarkan hasil penelitian, fitoplankton yang didapatkan pada Perairan Desa Lalanu terdiri dari 4 kelas yaitu Bacillariophyceae, Dinophyceae, Coscinodiscophyceaea, dan Cryptophyceaea yang ditemukan menyebar pada setiap stasiun pengamatan. Kelimpahan tertinggi berada pada stasiun I pada pengambilan sampel pagi hari dengan nilai 1022 sel/L, terendah berada pada stasiun I pagi hari dengan nilai $79 \mathrm{sel} / \mathrm{L}$. Keanekaragaman tertinggi berada pada stasiun 1 siang hari dengan nilai 1.52. Keseragaman tertinggi berada pada stasiun III sore hari dengan nilai 0.65. Sedangkan dominansi tertinggi pada sore hari dengan nilai 0.97 dan terendah pada stasiun 1 dengan nilai 0.24 .
\end{abstract}

Kata kunci: Kelimpahan Jenis, Fitoplankton, Keanekaragaman, Perairan Lalanu

\begin{abstract}
The structure of the phytoplankton community is influenced by the availability of light, the deeper the waters, the lower the light intensity in these waters. The purpose of this study was to analyze the phytoplankton community structure based on the temporal distribution in Lalanu Village waters. Data collection was carried out in January - February 2019 at three research stations. Phytoplankton sampling was carried out for 13 hours, namely morning - evening which was carried out 3 times with sampling time intervals in the morning, afternoon and evening. Based on the research results, the phytoplankton obtained in the waters of Lalanu Village consisted of 4 classes, namely Bacillariophyceae, Dinophyceae, Coscinodiscophyceaea, and Cryptophyceaea which were found to be scattered at each observation station. The highest abundance was at station I in the morning sampling with a value of 1022 cells / L, the lowest was at station I in the morning with a value of 79 cells / L. The highest diversity is at station 1 during the day with a value of 1.52 . The highest uniformity is at station III in the afternoon with a value of 0.65 . While the highest dominance in the afternoon with a value of 0.97 and the lowest at station 1 with a value of 0.24 .
\end{abstract}

Keywords: Species Abundance, Phytoplankton, Diversity, Lalanu Waters.

\section{Pendahuluan}

Indonesia memiliki sumberdaya hayati yang beranekaragam, khususnya di daerah pesisir dan lautan, tetapi pemanfaatan sumberdaya alam tanpa mempertimbangkan keseimbangan ekologi akan berdampak besar bagi manusia dan juga kerusakan pada ekosistem yang ada.Salah satu sumberdaya hayati yang mempunyai peranan penting dalam ekosistem lauta dalah fitoplankton.

Struktur komunitas fitoplankton merupakan susunan individu dari beberapa jenis/spesies yang terorganisis menjadi komunitas.Struktur komunitas dipengaruhi oleh arus, kecerahan dan suhu juga dipengaruhi oleh lama waktu perpindahannya di perairan yaitu berdasarkan waktu siang dan malam (temporal). Adapun faktor pembatas dari keberadaan fitoplankton yaitu cahaya,karena intensitas cahaya pada siang dan malam hari sangat berbeda (Basmi, 2000).

PerairanDesa Lalanu Kabupaten Konawe merupakan kawasan kaya akan sumber daya alam, baik yang ada dilingkungan perairan maupun daratan. Wilayah ini memiliki potensi perikanan yang besar, namun belum ada pengelolaan secara intensif. Dalam upaya 
mendukung kawasan ini sebagai penyedia sumberdaya perikanan yang lestari untuk pengembangan budidaya laut, maka kesuburan perairan harus dijaga dan dipertahankan. Fitoplankton sebagai indikator kesuburan di wilayah pesisir tersebut sampai saat ini belum ada yang melakukan.

\section{Bahan dan Metode}

Penelitian ini dilaksanakan dari bulan Januari - Februari 2019. Analisis sampel dilakukan di Laboratorium Produktivitas dan Lingkungan Perairan Fakulas Perikanan dan Ilmu Kelautan Universitas Halu Oleo, Kendari.

Survei pendahuluan dilakukan untuk mengetahui kondisi lokasi penelitian, penentuan titik stasiun penelitian, dan persiapan peralatan yang akan digunakan. Berdasarkan survey pendahuluan yang telah dilakukan, lokasi stasiun penelitian dan penentuan stasiun penelitian dilakukan berdasarkan kondisi lingkungan yang terdapat di Desa Lalanu Kabupaten Konawe (Gambar 1). Lokasi pengambilan sampel terdiri dari 3 stasiun. Stasiun I, terletak pada $3^{\circ} 53^{\prime} 18.63^{\prime \prime} \mathrm{LS}$ dan $122^{\circ} 36^{\prime} 41.33^{\prime \prime} \mathrm{BT}$, stasiun ini berada dekat pemukiman warga. Stasiun II, terletak pada $3^{\circ} 53^{\prime} 18.12^{\prime \prime} \mathrm{LS}$ dan $122^{\circ} 36^{\prime} 56.90 " \mathrm{BT}$, stasiun ini mengarah kearah laut lepas. Stasiun III, terletak pada $3^{\circ} 53^{\prime} 26.45^{\prime \prime} \mathrm{LS}$ dan $122^{\circ} 37^{\prime} 0.95$ "BT, stasiun ini letaknya dekat dengan vegetasi mangrove dan dekat dengan aliran sungai.
Pengambilan sampel fitoplankton dilakukan selama 18 jam yaitu siang hari-sore hari. Pengambilan sampel dilakukan sebanyak 3 kali dengan interval waktu pengambilan sampel tiap pagi hari jam 06-00 WITA, siang hari jam 12-00WITA, dan sore harijam 18-00 WITA, dengan menggunakan plankton net, berukuran mata jaring ukuran $25 \mu \mathrm{m}$. Pengambilan sampel fitoplankton dilakukan pada tiga titik pengambilan sampel.

Sampel fitoplankton diambil dengan cara menyaring airyang diambil disetiap tiga stasiun dengan menggunakan ember 10 liter mengambil sampel air 100 liter. Sampel tersebut disaring menggunakan plankton net dengan ukuran $25 \mu \mathrm{m}$, air sampel yang tersaring dimasukan dalam botol sampel volume $100 \mathrm{ml}$ dan diawetkan dengan menggunakan Formalin 4\% sebanyak 3-5 tetes.

Parameter fisika kimia perairan yang dianalisis, terdiri dari parameter fisika kimia yang dianalisis secara langsung di lapangan dan di laboratorium.Pengukuran parameter fisika dan kimia perairan dilakukan dengan mengambil sampel air pada masing-masing stasiun.Parameter yang diukur langsung di lapangan meliputi, pengukuran suhu dilakukan dengan menggunakantermometer. Pengukuran kecerahan dan kecepatan arus dilakukan di atas kapal dengan cara menurunkan layangan arus dan secchi diskke perairan kemudian mencatat hasil yang didapatkan.

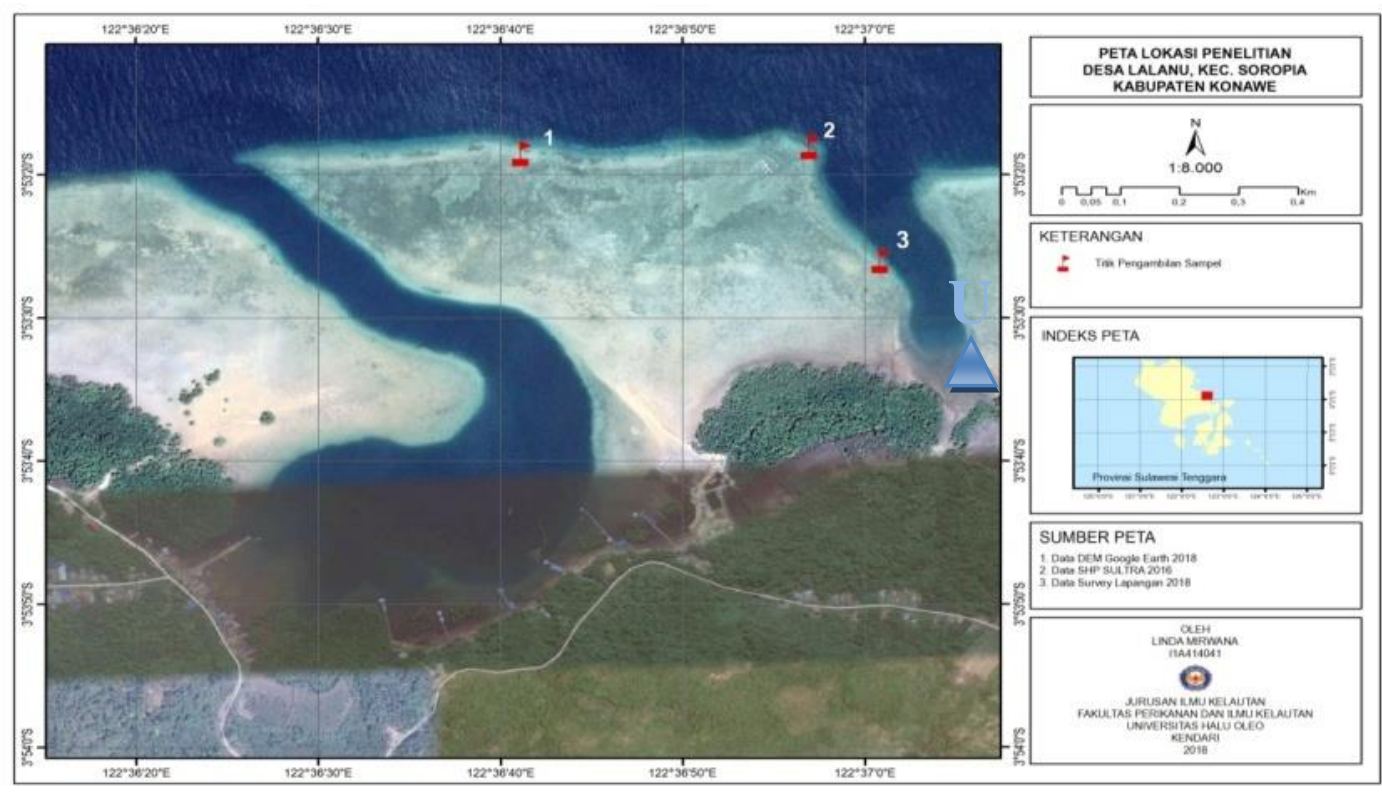

Gambar 1. Lokasi Penelitian di Perairan Perairan Desa Lalanu, Konawe 
Tabel 1. Alat dan bahan beserta kegunaannya

\begin{tabular}{|c|c|c|c|c|}
\hline No & Alat dan Bahan & Satuan & Kegunaan & $\begin{array}{c}\text { Jumlah } \\
\text { Unit }\end{array}$ \\
\hline \multirow[t]{7}{*}{$\mathbf{A}$} & Alat & & & \\
\hline & - Termometer & ${ }^{\circ} \mathrm{C}$ & Mengukur suhu perairan & 1 \\
\hline & - Secchi disk & $\mathrm{cm}$ & Mengukur kecerahan & 1 \\
\hline & - Layangan arus & $\mathrm{m} / \mathrm{det}$ & $\begin{array}{l}\text { Mengukur kecepatan arus } \\
\text { permukaan }\end{array}$ & 1 \\
\hline & - Luxmeter & $\operatorname{lux}$ & Mengukur intensitas cahaya & 1 \\
\hline & - Spektrofotometer & $\mathrm{mg} / \mathrm{L}$ & Menghitung Oksigen terlarut & 1 \\
\hline & - Plankton net & $25 \mu \mathrm{m}$ & Menyaring sampel air & 1 \\
\hline \multirow[t]{4}{*}{$\mathbf{B}$} & Bahan & & & \\
\hline & - Fitoplankton & sel & & \\
\hline & - Formalin $4 \%$ & $\mathrm{ml}$ & Bahan pengawet fitoplankton & 30 \\
\hline & - Larutan $\mathrm{H}_{2} \mathrm{SO}_{4}$ & $\mathrm{ml}$ & Bahan pengawet unsur hara & 15 \\
\hline
\end{tabular}

Pengambilan sampel air untuk analisis parameter kimia menggunakan botol sampel dengan volume $100 \mathrm{ml}$. Sampel air diperoleh dengan mengambil air pada setiap titik stasiun, pengambilan sampel air di perairan menggunakan ember untuk masing-masing stasiun pengamatan. Sampel air yang sudah diambil kemudian dimasukkan kedalam botol sampel ukuran $100 \mathrm{ml}$ dan diawetkan dengan menggunakan $\mathrm{H}_{2} \mathrm{SO}_{4}$ pekat sebanyak $0,5 \mathrm{ml}$ atau sekitar 10 tetes sampai $\mathrm{pH} 2$ untuk analisis parameter nitrat.

Sedangkan untuk parameter phospat, sampel air disaring menggunakan kertas saring.Selanjutnya sampel air dimasukkan ke dalam ice box untuk kemudian dibawah ke laboratorium dan disimpan di dalam freezer untuk di analisis, sampel air setelah dikeluarkan dari freezer dibiarkan terlebih dahulu sampai kondisi suhunya normal pada suhu kamar antara $26-28^{\circ}$ C.Parameter yang diukur di Laboratorium.

Pengukuran intesitas cahaya dilakukan dengan menggunakan Luxmeter yang dilakukan setiap 1 jam sekali yang dimulai pada pukul 06.00-17.00 WITA. Prinsip kerja alat ini adalah menangkap energi cahaya

Dari data yang diperoleh kemudian dilakukan analisis data untuk mengukur kelimpahan fitoplankton, indeks keanekaragaman, indeks keseragaman dan indeks dominansi.

Kelimpahan fitoplankton dihitung dengan metode sensus atau sapuan dengan matahari melalui sensor photo electric cell dan mengubahnya menjadi sinyal yang terbaca melalui luxselector, Nilai intensitas cahaya yang berada pada lapisan permukaan perairan, diperoleh dengan mengurangi nilai intensitas cahaya di daratan sebesar 10\% dengan asumsi bahwa intensitas cahaya mengalami refleksi oleh permukaan air laut (Kirk dan Othmer1998; Damar, 2003). Distribusi intensitas cahaya matahari pada setiap kedalaman kolom air ditentukan menurut hukum Beer-Lamber (Cole, 1988), sebagaimana pada persamaan berikut:

$\mathrm{I}_{\mathrm{z}}=\mathrm{I}_{0} \mathrm{e}^{-\mathrm{kz}}$

Keterangan:

$\mathrm{I}_{\mathrm{z}}=$ Intensitas cahaya pada suatu kedalaman $\mathrm{z}$

$\mathrm{I}_{\mathrm{o}}=$ Intensitas cahaya pada permukaan

perairan

e $=$ Bilangan dasar logaritma $(2,70)$

$\mathrm{k}=$ Koefisien peredupan

$\mathrm{z}=$ Kedalaman

Koefisien peredupan pada kolom perairan dihitung dengan membaca kedalaman keping secchi disk (Sd) dalam satuan meter dengan menggunakan persamaan empiris $\mathrm{k}=0,191+1,242 / \mathrm{Sd}\left(\mathrm{r}^{2}=\right.$ 0,853) (Tillman $d k k ., 2000$ ).

Sedwick Rafter Cell (SRC) menggunakan formula dari APHA (2005), yaitu:

$\mathrm{K}=\mathrm{N} / \mathrm{Ac} \times \mathrm{At} / \mathrm{Vs} \times \mathrm{Vt} / \mathrm{As}$

Keterangan :

$\mathrm{K}=$ Kelimpahan plankton (ind $\mathrm{I}^{-1}$ )

$\mathrm{N}=$ Jumlah plankton yang diamati

Ac $=$ Luas amatan $\left(\mathrm{mm}^{2}\right)$ 
At = Luas penampang permukaan SRC $\left(\mathrm{mm}^{2}\right)$

$\mathrm{Vs}=$ Volume konsentratdalam SRC (ml)

$\mathrm{Vt}=$ Volume konsentrat botolcontoh plankton (ml)

As $=$ Volume air disaring $(\mathrm{L})$

Indeks keanekaragaman jenis adalah suatu pernyataan atau penggambaran secara matematik yang melukiskan struktur kehidupan dan dapat mempermudah menganalisa informasi-informasi tentang jenis dan jumlah organisme. Penghitungan indeks keanekaragaman fitoplankton dilakukan dengan menggunakan Indeks ShannonWienner (Basmi, 2000) yaitu :

$\mathrm{H}^{\prime}=-\sum$ pi. $\ln \mathrm{pi}$; dengan $\mathrm{pi}=\mathrm{ni} / \mathrm{N}$

Keterangan :

$\mathrm{H}^{\prime}=$ Indeks keanekaragaman Shannon-

Wienner (nits/individu)

$\mathrm{ni}=$ Jumlah individu jenis ke-i

$\mathrm{N}$ = Jumlah total individu

Kisaran indeks keanekaragaman

Shannon-Wienner dapat dikategorikan sebagai berikut:

$\mathrm{H}^{\prime}<2,30=$ Keanekaragaman kecil dan kestabilan komunitas rendah. 2,30 < $\mathrm{H}^{\prime}<$ $6,91=$ Keanekaragaman sedang dan kestabilan komunitas sedang. $\mathrm{H}^{\prime}>6,91=$ Keanekaragaman tinggi dan kestabilan komunitas tinggi.

Indeks keseragaman ini digunakan untuk mengetahui berapa besar kesamaan penyebaran individu setiap marga pada tingkat komunitas. Indeks keseragaman berdasarkan persamaan Odum (1998) :

$\mathrm{E}=\frac{H^{\prime} \prime}{H^{\prime} \text { maks }}$

Keterangan :

$\mathrm{E}=$ Indeks keseragaman jenis

$\mathrm{H}^{\prime}=$ Indeks keanekaragaman Shannon-Wiener

H' maks= Nilai keanekaragaman maksimum ( Ln S)

$\mathrm{S}=$ Jumlah spesies

Dengan kriteria sebagai berikut :

$0<\mathrm{E} \leq 0,5=$ Komunitas tertekan

$0,5,<\mathrm{E} \leq 0,75=$ Komunitas labil

$0,75<\mathrm{E} \leq 1=$ Komunitas stabil.

Indeks dominansi dapat dihitung dengan menggunakan rumus indeks Simpson (Odum, 1998) sebagai berikut :

$D=\sum(\mathrm{Pi})^{2}$

Keterangan:

$\mathrm{D}$ = Indeks dominansi fitoplankton

pi $=(n i / N)$

ni $=$ Jumlah individu fitoplankton jenis ke-i
$\mathrm{N}=$ jumlah total individu fitoplankton

Dengan kriteria sebagai berikut :

$0<\mathrm{C} \leq 0,5=$ Komunitas kecil

$0,5<\mathrm{C} \leq 0,75=$ Komunitas sedang

$0,75<\mathrm{C} \leq 1=$ Komunitas tinggi

Jika diperoleh nilai $\mathrm{D}$ mendekati 0 $(<0,5)$ berarti tidak terdapat jenis yang mendominasi perairan dan apabila diperoleh nilai D mendekati $1(>0,5)$ berarti ada jenis fitoplankton yang mendominasi perairan tersebut.

\section{Hasil dan Pembahasaan}

Berdasarkan hasil penelitian, fitoplankton yang terdapat di Perairan Desa Lalanu Kabupaten Konawe terdapat 13 genera.Jumlah individu yang terbanyak yaitu chaetoceros sp. (kelas Bacillariophyceae) yang terdapat hampir semua stasiun dan interval waktu pengambilan sampel.Hal ini menujukkan bahwa jenis individu chaetoceros $s p$. memiliki penyebaran yang sangat luas. Kelimpahan fitoplankton tertinggi terdapat pada stasiun 1 pada waktu pagi hari dengan nilai 1022 sel/L dan yang terendah terdapat di stasiun 1 sore hari dengan nilai 79 sel/L. Kelas Bacillariophyceaemerupakan kelas fitoplankton yang paling melimpah hampir disemua stasiun dan disetiap interval waktu pengamatan dalam pengambilan sampel.Kondisi seperti ini merupakan hal yang sangat umum terjadi diperairan laut seperti yang dikemukakan oleh Abida(2010) bahwa genera fitoplankton dari kelas Bacillariophyceae ditemukan melimpah karena fitoplankton kelas tersebut merupakan anggota utama fitoplankton yang terdapat di seluruh bagian perairan laut, baik perairan pantai maupun perairan oseanik.

Tingginya kelimpahan fitoplankton pada stasiun Ipagi hari disebabkan penetrasi cahaya yang masuk saat pengambilan sampel berada pada titik optimal yang memungkinkan bagi fitoplankton untuk berfotosintesis di perairan, sesuai dengan pendapat Salwiyah (2010) kecerahan merupakan salah satu faktor pembatas bagi kehidupan fitoplankton karena mempengaruhi penetrasi cahaya yang masuk ke dalam perairan, Odum (1998) menyatakan bahwa penetrasi cahaya merupakan faktor utama yang mendukung fitoplankton untuk berfotosintesis di perairan. 
Tabel 2. Jenis-jenis fitoplankton yang ditemukan di Perairan Desa Lalanu.

\begin{tabular}{|c|c|c|c|c|}
\hline No & Kelas & Ordo & Family & Genus \\
\hline \multirow[t]{9}{*}{1} & Bacillariophyceae & Bacillarialcs & Chaetoceraceae & Chaetoceros sp. \\
\hline & & Pennales & Fragilariaceae & Synedra \\
\hline & & Pennales & Naviculaceae & Navicula \\
\hline & & Pennales & Nitzschiaceae & Nitzschia sp. \\
\hline & & Pennales & Tabellariaceae & Diatoma \\
\hline & & Pennales & Tabellariaceae & Tabellaria \\
\hline & & Eunotiales & Eunotiaceae & Eunotia \\
\hline & & Thalassionematales & Thalassionemataceae & Thalassionema \\
\hline & & Licmophorales & Licmophoraceae & Licmophora \\
\hline \multirow[t]{2}{*}{2} & Dinophyceae & Peridiniales & Peridiniaceae & Peridinium \\
\hline & & Peridiniales & Protoperidiniaceae & Protoperidinium \\
\hline 3 & Cyanophyceae & Osscillatoriales & Oscillatoriaceae & Oscillatoria \\
\hline 4 & Coscinodiscophyceae & Coscinodiscales & Coscinodiscaceae & Coscinodiscus \\
\hline
\end{tabular}

Rendah kelimpahan fitoplankton pada stasiun I pengambilan sampel sore hari disebabkan oleh kecepatan arus yang tinggi yakni $0,85 \mathrm{~m} /$ det sehingga memengaruhi pergerakan fitoplankton, kecepatan arus merupakan faktor sebaran fitoplankton tidak merata di perairan Desa Lalanu. Hal ini didukung oleh Lasri dkk, (2013) menyatakan bahwa kecepatan arus merupakan parameter penting sehubungan dengan keberadaan fitoplankton, arus yang kencang dapat memengaruhi distribusi fitoplankton pada suatu perairan maka secara tidak langsung juga berpengaruh terhadap kelimpahan fitoplankton. Menurut Wijayanti (2007) arus dari $0,1 \mathrm{~m} / \mathrm{det}$ termasuk kecepatan arus yang sangat kuat, sedangkan kecepatan arus sebesar 0,1-1 $\mathrm{m} / \mathrm{det}$ tergolong kecepatan arus yang sedang, dan kecepatan arus > $1 \mathrm{~m} / \mathrm{det}$ tergolong kecepatan arus yang lemah. Dengan demikian kecepatan arus yang didapatkan di perairan Desa Lalanu di stasiun I pengambilan sampel sore hari merupakan kecepatan arus dalam keadaan tinggi.

Selain intensitas cahaya, nitrat dan posfat juga mempengaruhi kelimpahan fitoplankton perairan.Kedua faktor ini sangat mempengaruhi kehidupan fitoplankton didalam suatu perairan karena berperan penting dalam proses fotosintensis yang dilakukan oleh organisme fitoplankton tersebut. Kelimpahan komunitas fitoplankton diperairan sangat berhubungan dengan kandungan nutrien seperti phospat, nitratdan hara lainnya.Kandungan nutrien dapat mempengaruhi kelimpahan fitoplankton dan sebaliknya fitoplankton yang padat dapat menurunkan kandungan nutrien dalam air. Perubahan komposisi fitoplankton selanjutnya dapat mempengaruhi komposisi zooplanktondan komunitas plankton secara keseluruhan dalam suatu ekosistem (Pugesehan, 2010).

Selain intensitas cahaya dan nutrient, suhu perairan yang normal yaitu berkisar antara $26-30^{\circ} \mathrm{C}$ juga memengaruhi kelimpahan fitoplankton, hal ini sesuai dengan pernyataan Ambiasa (2007) bahwa suhu air yang baik bagi kelangsungan hidup dan perkembangan plankton berkisar antara $20-30^{\circ} \mathrm{C}$. Menurut Manigasi (2013), suhu perairan memengaruhi keberadaan fitoplankton secara fisiologis dan ekologis. Secara fisiologis perbedaan suhu perairan sangat berpengaruh terhadap ukuran fitoplankton.Secara ekologis, perubahan suhu menyebabkan perbedaan komposisi dan kelimpahan fitoplankton. 


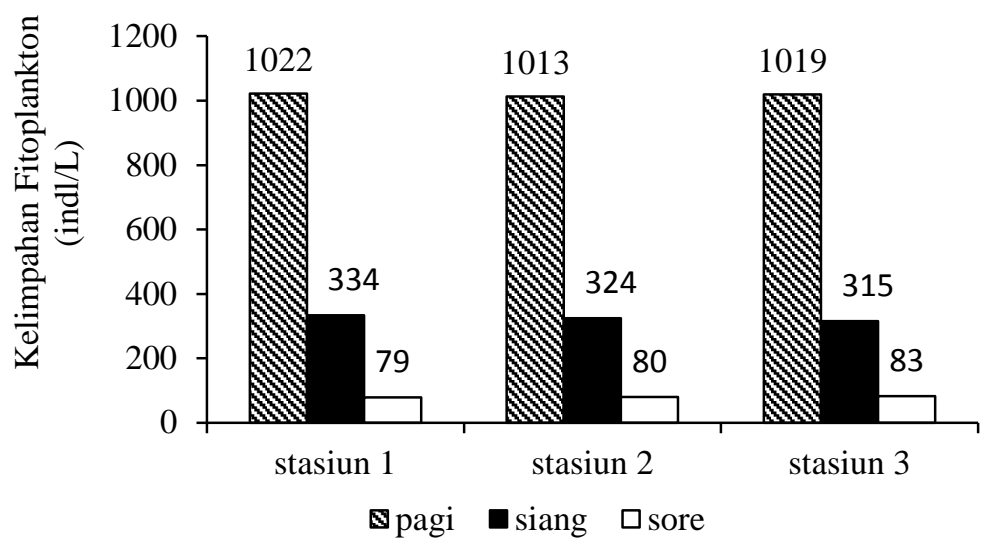

Gambar 2. Kelimpahan Fitoplankton berdasarkan waktu pengambilan sampel

Nilai keanekaragaman berada pada kategori rendah dengan yang didapatkan berada pada stasiun 3dengan nilai 0,8 dan terendah berada pada stasiun 2 dengan nilai 1,52 , hal ini sesuai dengan pendapat Odum (1998) yang menyatakan bahwa kisaran nilai indeks keanekaragaman $0-1$ menunjukkan bahwa daerah tersebut terdapat tekanan ekologis yang tinggi dan indeks keanekaragaman yang rendah dengan sebaran individu yang tidak merata dan kestabilan komunitas rendah. Nilai indeks keanekaragaman yang didapatkan dalam penelitian ini diduga tidak terlepas dari tingkat kelimpahan fitoplankton yang ditemukan pada penelitian ini, karena semakin rendah atau melimpahan fitoplankton maka akan semakin rendah atau melimpah pula keanekaragaman fitoplankton dalam suatu perairan. Hal ini sesuai pendapat Siagian (2012) yang mengatakan bahwa nilai kelimpahan rendah pada suatu komunitas maka tingkat indeks keanekaragamannya juga akan menurun karena keanekaragaman ditentukan oleh jumlah jenis dan jumlah individu dalam suatu komunitas.
Berdasarkan nilai keseragaman yang diperoleh menunjukkan bahwa nilai keseragaman berada pada kategori merata dengan hasil perhitungan yang dilakukan, nilai keseragaman tertinggi berada pada stasiun 3 sore dengan nilai 0,65 dan terendah berada pada stasiun 1 dengan nilai 0,11 . Hal ini sesuai pendapat Andi dan Burhanuddin (2015) yang mengatakan jika nilai $\mathrm{E}<0,4$, maka keseragaman berada pada kategori rendah, jika $0,4<\mathrm{E}<0,6$ maka keseragaman berada pada kategori sedang, dan jika $\mathrm{E}>0,6$ maka keseragaman berada pada tingkat yang tinggi. Meratanya penyebaran individu fitoplankton pada Desa Lalanu diduga karena intensitas cahaya yang masuk kedalam perairan cukup untuk kehidupan fitoplankton (Gambar 3 dan 4) serta tiupan angin yang menyebabkan kurangnya gelombang atau ombak yang dapat mempengaruhi distribusi fitoplankton.Hal ini sesuai pendapat Andi dan Burhanuddin (2015) bahwa tiupan angin mempengaruhi keseragaman fitoplankton yang menyebabkan penumpukan disuatu tempat.

Tabel 3. Keanekaragaman Fitoplankton (H'), Keseragaman Fitoplankton (E) dan Dominansi Fitoplankton (D).

\begin{tabular}{ccccc}
\hline Stasiun & Waktu Pengambilan Sampel & Keanekaragaman & Keseragaman & Dominansi \\
\hline I & Pagi & 0.59 & 0.11 & 0.97 \\
& Siang & 1.52 & 0.41 & 0.28 \\
& Sore & 0.85 & 0.21 & 0.58 \\
II & Pagi & 0.61 & 0.12 & 0.77 \\
& Siang & 0.34 & 0.06 & 0.84 \\
& Sore & 0.89 & 0.34 & 0.43 \\
III & Pagi & 0.68 & 0.13 & 0.92 \\
& Siang & 1.49 & 0.45 & 0.24 \\
& Sore & 1.5 & 0.65 & 0.24 \\
\hline
\end{tabular}


Tabel 4. Rata-rata hasil pengukuran unsur hara pada setiap kedalaman

\begin{tabular}{cccc}
\hline \multirow{2}{*}{ Stasiun Pengamatan } & Waktu & \multicolumn{2}{c}{ prameter } \\
\cline { 3 - 4 } & & Nitrat $(\mathrm{mg} / \mathrm{L})$ & Ortophosphat $(\mathrm{mg} / \mathrm{L})$ \\
\hline \multirow{3}{*}{ stasiun I } & Pagi & 0.0073 & 0.0648 \\
& Siang & 0.0067 & 0.0618 \\
& Sore & 0.0041 & 0.1018 \\
& Pagi & 0.0055 & 0.08 \\
stasiun II & Siang & 0.0061 & 0.3395 \\
& Sore & 0.0058 & 0.0838 \\
& Pagi & 0.0026 & 0.0693 \\
\multirow{2}{*}{ stasiun III } & Siang & 0.0046 & 0.0638 \\
& Sore & 0.0071 & 0.0582 \\
\hline
\end{tabular}

Tabel 5. Rata-rata hasil pengukuran parameter fisika perairan selama penelitian

\begin{tabular}{ccccc}
\hline \multirow{2}{*}{ Stasiun Pengamatan } & Waktu & \multicolumn{3}{c}{ prameter fisika perairan } \\
\cline { 3 - 5 } & Pagi & 29,8 & Kecepatan arus ( m/detik) & Kecerahan ( \%) \\
\hline \multirow{2}{*}{ I } & Siang & 28,3 & 0,04 & $100 \%$ \\
& Sore & 26,8 & & \\
II & Pagi & 30 & 0,07 & $100 \%$ \\
& Siang & 28,8 & & $100 \%$ \\
& Sore & 27,5 & 0.08 & \\
\hline \multirow{2}{*}{ III } & Pagi & 29,3 & & \\
& Siang & 29 & &
\end{tabular}

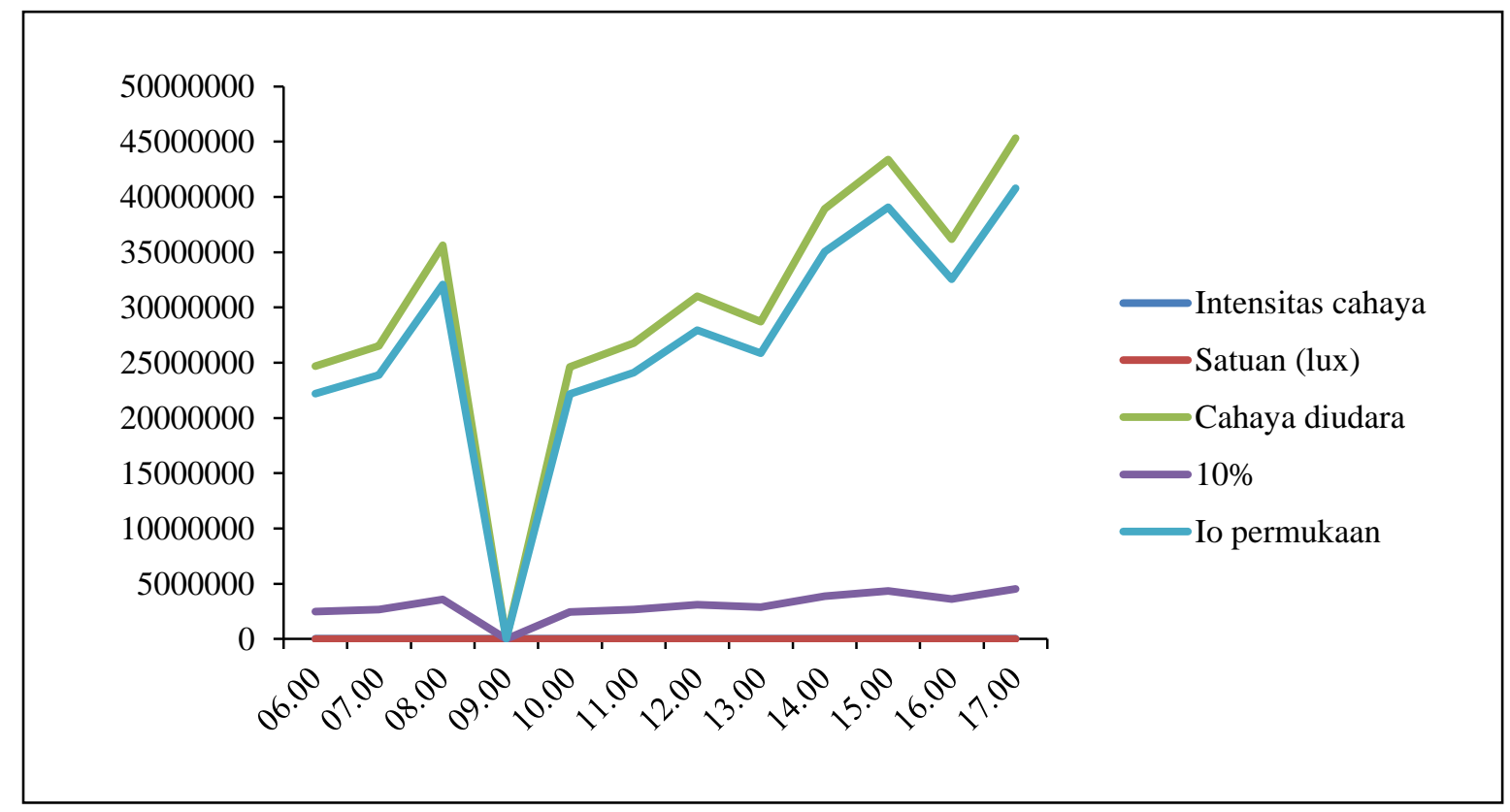

Gambar 3. Rata-rata nilai intensitas cahaya permukaan dan udara selama penelitian 
Berdasarkan hasil perhitungan yang dilakukan hal ini mengindikasikan bahwa dalam struktur komunitas fitoplankton pada perairan Desa Lalanu terdapat spesies yang mendominasi diantara spesies-spesies lain. Ada beberapa spesies yang tidak memiliki peluang untuk dapat tumbuh dan berkembang dengan baik. Hal ini menunjukkan bahwa kondisi struktur komunitas dalam keadaan tidak stabil, hal ini sesuia dengan pendapat Odum (1998) yang menyatakan bahwa bila nilai $\mathrm{C}$ mendekati $1(\geq 0,5)$ berarti di dalam struktur komunitas biota yang diamati terdapat spesies yang secara ekstrim mendominasi spesies-spesies yang lainnya. Jika kita melihat dari setiap stasiun pada penelitian ini, angka dominansi semua mendekati 1 sehingga dapat dijelaskan bahwa secara umum di perairan Desa Lalanu ada jenis fitoplankton yang mendominasi jenis lainnya selama penelitian ini berlangsung.

Berdasarkan hasil pengamatan dalam penelitian yang telah dilakukan, nilai intensitas cahaya permukaan dari jam $06.00-17.00$ WITA berada pada nilai 43392-45321.3 Lux, pada udara nilai intensitas cahaya dari jam 06.00-17.00 berada pada nilai 2461490045321300Lux.

\section{Simpulan}

Kelimpahan tertinggi berada pada daerah dekat pemukiman warga pada waktu pagi hari dengan nilai $1022 \mathrm{sel} / \mathrm{L}$ dan terendah berada dekat pemukiman warga dengan nilai $79 \mathrm{sel} / \mathrm{L}$ sore hari .Indeks keanekaragaman tertinggi berada dekat pemukiman warga dengan nilai 1,52 siang hari dan terendah berada mengarah laut lepas dengan nilai 0,34 siang hari.Indeks keseragaman tertinggi berada dekat dengan vegetasi mangrove dan paliran sungai dengan nilai 0,65 sore hari dan terendah berada dekat pemukiman warga dengan nilai 0,11 pagi hari. Indeks dominansi tertinggi berada pada dekat pemukiman warga dengan nilai 0,97 pagi hari dan terendah berada pada dekat vegetasi mangrove dan aliran sungai dengan nilai 0,24 siang dan sore hari. Kelas yang mendominasi pada penelitian yaitu kelas Bacillariophyceae.

\section{Daftar Pustaka}

Abida I. W. 2010. Struktur Komunitas Dan Kelimpahan Fitoplankton Di Perairan Muara Sungai Porong Sidoarjo.Jurnal Kelautan. Volume 3.No.1.Hal : 36-40.
Ambiasa, I.K. 2007. Distribusi Spasial Fitoplankton dan Zooplankton di Teluk Jakarta.Skripsi.Fakultas Perikanan dan Ilmu Kelautan IPB. Bogor: 80 hal.

Andi, K., dan Burhanuddin. 2015. Studi Kelimpahan dan Sebaran Phytoplankton Secara Vertikal di Pesisir Perairan Kuricaddi (Untuk Peruntukkan Budidaya Ikan dan Udang). Jurnal Ilmu Perikanan. Octopus. Vol. 4.No. 2. Hal: 427-434.

APHA (American public health association), 1989. Standard methed for the axaminatin $d f$ water and wastewater American public control federation. 19 edition Washington DC. American public health association inc.

Basmi, 2000.Planktonologi, sebagai bioindikator kualitas air. Fakultas perikanan dan Ilmu kelautan IPB bogor.

Cole, G.A. 1988. Textbook of Limnology.Third Edition. Waveland Press, Inc.,Illinois, USA. pp: 401.

Damar, A. 2003. Effects of enrichment on nutrient dynamics, phytoplankton dynamics and productivity in Indonesian tropical waters: a comparison between Jakarta Bay, Lampung Bay, and Semangka Bay. 196 p.

Kirk dan Othmer, 1998. Encyclopedia of Chemical Technology. $4^{\text {nd }}$. ed. Vol 7. Interscience Willey.

Lasri, Desy, A., Endarwati, H., Santoso, G. W. 2013. Struktur Komunitas Plankton di Perairan Desa Mangurharjo Kecamatan Tugu Semarang.Jurnal of Marine Research. 2(3): 197- 204 hlm.

Manigas.2013. Kelimpahan Dan Keanekaragaman Plankton di Perairan Laguna Desa Tolongano Kecamatan Banawa Selatan.Jurnal. VOL III (2):119123. Universitas Tadulako (UT): Sulawesi Tengah.

Odum, E.P. 1998. Dasar-dasar Ekologi : Terjemahan dari Fundamentals of Ecology. Alih Bahasa Samingan, T. Edisi Ketiga.Universitas Gadjah Mada Press, Yogyakarta. 697 p.

Pugesehan, D. J. 2010. Analisis Klorofil-A Fitoplankton (Produktivitas Primer) di Perairan Pantai Netsepa Kabupaten Maluku Tengah.Politeknik Perdamaian 
Halmahera.Tobelo. J. Agroforesti. V (4): 272-278.

Salwiyah.2010. Kondisi Kualitas Air Sehubungan Dengan Kesuburan Perairan Sekitar PLTU NII Tanasa Kabupaten Konawe Provinsi Sulawesi Tenggara.Warta-Wiptek.Vol. 18.No. 2. Hal: 52-57.

Siagian. M. 2012. Jenis dan Keanekaragaman Fitoplankton di Waduk PLTA Koto PPanjang, Kampar, Riau. Jurnal Bumi Lestari. Vol. 12. No 1. Hal: 99-105.

Tillman, U., KJ. Hesse dan F. Colijn. 2000. Plantonic Primary Production in The German Wadden Sea. Journal Plankton Research. 22 (7) : 1253-1276.

Wijayanti.2007. Keanekaragaman Jenis Plankton Pada Tempat Yang Berbeda Kondisi Lingkungannya Di Rawa Pening Kabupaten Semarang. Skripsi. IKIP PGRI Semarang. 